Educational Research for Social Change (ERSC)

Volume: 5 No. 2, September 2016

pp. 117-135

ersc.nmmu.ac.za

ISSN: 2221-4070

\title{
"Hear Our Voices": A Collective Arts-Based Self-Study of Early- Career Academics on Our Learning and Growth in a Research- Intensive University
}

\author{
L. Masinga \\ University of KwaZulu-Natal \\ Masingal@ukzn.ac.za \\ (Author 1) \\ A. Singh-Pillay \\ University of KwaZulu-Natal \\ Pillaya5@ukzn.ac.za \\ (Author 4) \\ P. Mweli \\ University of KwaZulu-Natal \\ Mwelip@ukzn.ac.za \\ (Author 7)
}

\author{
P. Myende \\ University of KwaZulu-Natal \\ Myendep@ukzn.ac.za \\ (Author 2) \\ M. Kortjass \\ University of KwaZulu-Natal \\ KortjassM@ukzn.ac.za \\ (Author 5)
}

\author{
A. Marais \\ University of KwaZulu-Natal \\ Maraisa@ukzn.ac.za \\ (Author 3) \\ T. Chirikure \\ University of KwaZulu-Natal \\ Chirikure@ukzn.ac.za \\ (Author 6)
}

\section{Abstract}

Early-career academics (ECAs) experience challenges with their integration into higher education institutions due to what is considered inadequate (or lack of) provision for effective professional development. In this article, we present our journey through a collective arts-based self-study project as ECAs guided by three seasoned academics: Kathleen Pithouse-Morgan, Daisy Pillay, and Inbanathan Naicker. We share our personal experiences and challenges faced as ECAs at the University of KwaZulu-Natal; to achieve this, we used a social constructivist lens to collectively engage in conversations as we constructed new understandings of ourselves and experiences as ECAs. We show how, through the research, we learned to form and position our learning and growth within the changing university setting. We adopted a collective arts-based, self-study approach to explore our experiences and what we felt needed to happen to provide meaningful development for the newly appointed as we journey through the unclear grounds of university life. We make visible how we as ECAs feel overwhelmed when entering higher education institutions because of the need to balance research, teaching, and other demands of academic life. We find a strong need for collaborative engagement between ECAs and experienced academics. In addition, establishment of a healthy working environment and policy specific to addressing the needs of ECAs would assist in providing clear support as ECAs transition into experienced academics. Finally, we demonstrate how we took our findings forward, and describe both the resistance and support we experienced. 
Keywords: Early-career academics, arts-based collective, self-study, poetry, lived experiences, professional development

Copyright: (C) 2016 Masinga et al.

This is an open access article distributed under the terms of the Creative Commons Attribution Non-Commercial License, which permits unrestricted non-commercial use, distribution, and reproduction in any medium, provided the original author and source are credited.

\section{Please reference as:}

Masinga, L., Myende, P., Marais, A., Singh-Pillay, A., Kortjass, M., Chirikure, T \& Mweli, P. (2016).

"Hear Our Voices": A Collective Arts-Based Self-Study of Early-Career Academics on Our Learning

and Growth in a Research-Intensive University. Educational Research for Social Change, 5(2), 117-

135. http://dx.doi.org/10.17159/2221-4070/2016/v5i2a8

\section{Introduction}

Since 1994, the South African higher education sector has faced significant changes and challenges in its attempt to build an education system appropriate for a democratic society (Department of Higher Education and Training [DHET], 2013). Some key changes include the merger and integration process that occurred between 2002 and 2005, resulting in 46 universities and technikons merging to form a total of 23 (now 26) universities (Harrison, Pithouse-Morgan, Conolly, \& Meyiwa, 2012) as well as the establishment of the DHET in 2009.

A key challenge faced by the sector in its transformation process is the attraction and development of new and inexperienced academics (Balfour \& Lenta, 2009; DHET, 2013). Flowing from this challenge, the DHET $(2013,2015)$ established, as one of its key priorities, the expansion of the academic profession and development of early-career academics (ECAs) through mentorship and support. Through this priority, DHET hopes to respond to the National Planning Commission's (2013) National Development Plan (NDP) 2030, which indicates that an estimated 4,000 academics from South African higher education institutions (HEIs) will retire by the year 2018. This requires focused strategies for creation of the next generation of researchers.

To align itself with the priorities of DHET and the NDP and to address the challenge of retiring seasoned academics, our university has embarked on a process of employing ECAs. As stated earlier, attracting these academics is a challenge-but a further pressing challenge is their development and nurturing into productive researchers (Balfour \& Lenta, 2009). In this article, we demonstrate through the literature that there are different meanings of what it means to be an ECA but research on how to address the challenge of developing and nurturing ECAs, especially within the South African context, appears to be at the periphery. To address this research gap, we share in this article our personal experiences and challenges that we face as ECAs in a research-intensive university. The article shows how, through a collective arts-based self-study project, we learned to form and position our learning and growth within the changing university setting.

The article begins with conceptualising ECAs and justifying the need for prioritising their professional learning and development. After the conceptualisation of ECAs, we explain the nature and purpose of the collective arts-based self-study project though which we explored our experiences as ECAs. We use a social constructivist lens for understanding our experiences, and how we learn and position our growth within a transforming university environment. We then explain the methodology informing our research, and our experiences are thereafter presented in the form of data presentation and interpretation. 
To conclude we offer some lessons for other ECAs and university communities about how professional learning and development of ECAs can be understood and enhanced, given that they contribute to the future performance of all HEls and knowledge production in the country.

\section{The Context of ECAs and Professional Learning and Development for ECAs}

The professional development and support needed by ECAs has become an attractive phenomenon in local and international scholarly conversations (Geber, 2009; Geber \& Nyanjom, 2009; Hopwood \& Stocks, 2009; Price, Coffey, \& Nethery, 2015; Remmik, Karm, Haamer, \& Lepp, 2011; Thomas, McNaught, Wong, \& Li, 2011). To fully understand the needs of ECAs, however, it is first necessary to identify who constitutes an ECA. In this regard, Price et al. (2015) argued that there is no agreed definition of what characterises an ECA, and they regard this as one of the major challenges for institutions trying to provide support to ECAs. In this article, we draw on Hemmings' (2012) definition, which states that ECAs are those academics who are within their first five years as members of staff in HEls under a sessional, part-time, or full-time load. We also draw from Price et al. (2015), who explained ECAs as an inclusive concept towards understanding the characteristics and identities of those who have limited experience in academia. These definitions illuminate the varying nature of contractual arrangements under which ECAs can be employed (Price et al., 2015). In the case of our project, many of the ECA project participants were appointed as developmental lecturers ${ }^{1}$ because they are still pursuing their doctoral studies.

Once an ECA is identified, it becomes possible to identify her or his professional development and support needs. The dominant discourse in this regard focuses on the transition that occurs when ECAs take jobs as lecturers or postdoctoral students, and the kind of professional development and support they require (Remmik et al., 2011). Other conversations have examined the experiences of ECAs and the implications for their professional development (Thomas et al., 2011).

In our view, the position taken by different institutions in understanding ECAs determines the kind of professional development and support that is considered desirable for them. While there seem to be different perspectives on the needs of ECAs, there is a common understanding that many ECAs lack research networks and remain poorly informed about the structures and culture of academic institutions (Geber, 2009; Hemmings \& Kay, 2010). Resonating with Hemmings and Kay (2010), Laudel and Gläser (2008) stressed that ECAs continue to be the most defenceless group in universities because they more easily experience anxiety compared to experienced scholars; they experience job insecurity, workload pressures, and professional isolation (Price et al., 2015). This possibly also resonates from "the pressure to publish and increased demands for accountability" (Pithouse-Morgan, Naicker, Pillay, Masinga \& Hlao, 2016, p. 3).

While ECAs have to deal with this cocktail of dilemmas, it is commonly known that ECAs are invaluable future academic assets of HEls because many experienced academics are at their exit stage (Warhurst, 2008). If we are to address some or all of these issues, we argue that institutions must provide professional development that is also informed by "early-career colleagues' stories of experience" (Pithouse-Morgan et al., 2016, p. 4). In South Africa, professional support and development for ECAs has been advocated on the basis that it is a tool to fast-track the transformation agenda in HEls (Balfour \& Lenta, 2009) and the creation of the next generation of academics.

1 Guided by the NDP, our university embarked on a process of creating a new generation of academics. To create this pool, the relaxation of rules and requirements for a person to be employed as a lecturer was implemented. People with a master's degree or doctorate, but with no experience in higher education, were employed and these academics are called developmental lecturers. 


\section{The Project and Its Purpose}

In light of this need to provide professional development to ECAs, three senior academics, Kathleen Pithouse-Morgan, Daisy Pillay and Inbanathan Naicker from the School of Education at a South African research-intensive university (University of KwaZulu-Natal), in collaboration with the university's Teaching and Learning Office (UTLO) initiated the New Scholarship in Teaching and Learning in Higher Education Project. The purpose of the project was twofold. The first objective was for ECAs from a wide range of disciplines within the university to be involved in collective arts-based self-study research, reflecting on their personal experiences and challenges. The second objective was to assist these ECAs in shaping and organising their learning, and developing their agency-both individually and collaboratively-as they journey to become seasoned academics. Hence, the purpose of this article is to highlight the personal experiences and challenges that the ECAs shared within the project and to demonstrate how, through the project, these ECAs developed and learned to form and arrange their own scholarship and growth within the institution.

\section{Project participants and activities.}

As mentioned, ECAs who participated in the project came from diverse disciplines within the university and were all within their first five years of appointment. The invitation to participate in the project was issued to all 198 ECAs within the university through the UTLO office, using the human resource database (Pithouse-Morgan et al., 2016). Eventually 16 ECAs participated. Four workshops were held in the project, one being led by Anastasia P. Samaras, an international scholar in self-study research (Samaras, 2011). It was within this series of workshops that we were introduced to the concept of artsbased self-study, which allowed us space to engage with different forms of data production practices to address the objectives of the project. The workshops were supported by an online classroom hosted on Edmodo (www.Edmodo.com), where continuous communication and discussions were held, which went beyond the boundaries of the workshops. This facilitated an online platform for ECAs and the mentors (the three senior academics from the School of Education) to strengthen the discussion and sharing of information.

The project culminated in a seminar in May 2015 at which we reported our findings to the wider university community and made recommendations. A further presentation was made in September 2015 at the university's annual Teaching and Learning in Higher Education Conference, which focused on re-imagining higher education policy and practice. Table 1 provides a summary of the project activities. 
Table 1: Summary of Project Activities

\begin{tabular}{|c|c|c|}
\hline Date & Activity & Data generated \\
\hline 27 June 2014 & Introduction of project to participants & $\mathrm{N} / \mathrm{A}$ \\
\hline 24-25 July 2014 & $\begin{array}{l}\text { Workshop with international scholar, } \\
\text { Professor Anastasia P. Samaras }\end{array}$ & $\mathrm{N} / \mathrm{A}$ \\
\hline 22 September 2014 & Workshop on artefacts & $\begin{array}{l}\text { Written reflections on own } \\
\text { artefacts }\end{array}$ \\
\hline 8-9 December 2014 & Data production workshop & $\begin{array}{l}\text { Development of collages, concept } \\
\text { maps, and pantoum poems }\end{array}$ \\
\hline \multirow[t]{2}{*}{31 March 2015} & Preparation workshop for the UTLO seminar & $\begin{array}{l}\text { Discussion of findings and } \\
\text { recommendations }\end{array}$ \\
\hline & & Development of tanka poem \\
\hline 28 May 2015 & UTLO seminar & $\begin{array}{l}\text { An audio recording of the seminar } \\
\text { as well as audience questions and } \\
\text { responses }\end{array}$ \\
\hline 21 September 2015 & 9th Teaching and Learning Conference & $\begin{array}{l}\text { Audio recording of the conference } \\
\text { presentation as well as audience } \\
\text { questions and responses }\end{array}$ \\
\hline
\end{tabular}

\section{Ethical considerations}

Given the collaborative self-study nature of the research project, it was of paramount importance to protect the rights of the participants (Samaras, 2011). These rights include issues of respect, confidentiality, and the right to withdraw from the research at any time. In the project's first meeting, the three seasoned academics clarified the intentions of the project. Following the governing rules of ethics ${ }^{2}$ in research of the institution, we signed letters of informed consent. Also, as participants who are also researchers in our own right, we understood what was being asked of us and we gave our commitment and consent to the process. Multiple opportunities for all participants to ask questions and clarify the roles, purposes, and outcomes of the research were constantly provided by the mentors.

\section{Theoretical stance of the project}

In our collective endeavour, we embraced a social constructivist lens to facilitate our journey as ECAs as we shared our personal experiences and challenges. This allowed us to form a learning environment that permitted a rich inquiry-based dialogue among us as ECAs (Taylor, 2014). We grappled intensely with matters that were significant to us (Philpott $\&$ Batty, 2009) as we engaged in a social interaction process that promoted collaborative engagement (Powell \& Kalima, 2009). In this way, we got an opportunity to coconstruct meaningful knowledge about ourselves as ECAs that would propel us to become future veteran academics (Taylor, 2014). In the process, we gained deeper insights into our understanding of our workspace through verbal communication that prompted us to interrogate, challenge, and negotiate as we responded to our sense of agency (Philpott \& Batty, 2009).

Social constructivism permitted us to view ourselves as self-motivated professionals experiencing constant reconstruction (Taylor, 2014). Through communication, we engrossed ourselves in an interchange as we critically thought about what it was we were learning about ourselves and the institution in which we are employed. Social constructivism, through its nature of promoting

2 The ethical clearance number for the project: HSS/1116/013. 
interaction amongst individuals in a group, allowed us to use innovative ways of promoting our thinking (Philpott \& Batty, 2009). In our professional learning, we gained a deeper understanding of our experiences when we created arts-based resources related to our learning of who we are as ECAs (Polly, 2011).

We wanted to acquire knowledge through a constructive process where we endeavoured to organise and reorganise our practices in the light of prevailing structures that exist in our institution (Bodner, Klobuchar, \& Geelan, 2001). In organising and reorganising we created our understanding of how we need to develop as early academics (Richardson, 1997). We jointly took accountability to acquire new approaches or tactics to increase our efficacy in our work (Hord, 2009).

\section{Methodological Approach}

To facilitate our venture in understanding our collective experiences and our professional development support needs, we used a collective arts-based self-study research approach. A collective self-study approach allowed for an engagement in an interactive examination of experiences and the issues of policy and practice in a cooperative research process (Samaras, 2011). Arts-based research allowed for systematic use of the artistic process to understand, engage in critical enquiry, exchange ideas, stimulate self-reflexivity, and examine diverse and collected experiences in professional development (Weber, 2014). Also, arts-based research allowed for creative analytic practices that are both scientific (in the sense of being true to a world known through empirical research) and artisticin the sense of expressing what has been learned through evocative writing and visual art forms (Richardson \& St Pierre, 2005). The images and works of art created allowed access to different levels of consciousness and many conversations with the self and others, thereby communicating a holistic picture of "what is" or the authenticity of the experience (Prosser \& Loxley, 2008). In other words, through arts-based research we were allowed opportunities for new ways of seeing, understanding, and connecting. Thus, the arts-based texts we created were used to invite collaborative interpretative responses.

In a full-day workshop session, we worked in four groups that consisted of four participants in each as we followed a structured process of creating collages. From these collages, we then drew up concept maps that we used as "graphical tools for organizing and representing knowledge" (Novak \& Cañas, 2008 , p. 1). Finally, based on words and phrases found in the concept maps, we derived pantoum poems that expressed our feelings. The tanka poem was then developed together as a way of making collective meaning and suggestions for change from the set of collages, concept maps, and pantoum poems.

The rationale for these elements within our structure is now explained and then followed by the data generation and interpretation.

\section{Collages}

Our first artwork was the creation of a collage because it provided "different ways of knowing and understanding" the phenomenon (Mannay, 2010, p. 98-99). Collage making is a "creative arts-based method in which separate images are cut from magazines, news articles and/or books and glued together to create a new image" (Raht, Smith, \& MacEntee, 2009, p. 229). This "process of using fragments of found images or materials and gluing them to a flat surface [is done] to portray [the] phenomena" (Butler-Kisber \& Poldma, 2010, p. 2). As explained by Threadgold (2003), these images represent feelings and experiences of the participants. The collage making process encouraged active participation, critical engagement, and reflexivity, and the end products were a holistic portrayal of the needs and experiences of ECAs as suggested by van Schalkwyk (2010). 
By combining collage making with written modes of expression we were able to create concept maps from our collages.

\section{Concept maps}

Concept maps are graphical tools that organise, connect, and force the researcher to blend information between important sets of concepts (Kilic \& Cakmak, 2013). As explained by van Schalkwyk (2010), concept maps assist in taking images and pictures from the collages created and making accurate meaning of them through methodical classification. They provide a means of viewing the construction of knowledge and an effective way to access that knowledge (Williams, 1998). The concept maps assisted us to concentrate on making meaning of what we were experiencing. We were able to see our meaning as well as connections that we deliberated on across concepts or bodies of knowledge (Daley, 2004). We were able to transcribe meanings made through our different collages into concept maps about ECAs' experiences of professional learning and development.

From our concept maps, we then composed pantoum poems - the equivalent literary arts-based versions of our visual concept maps-as we further made meaning of our collective self-study process.

\section{Poems}

We extracted words and phrases from our concept maps to create a special type of poetic narrative called a pantoum poem, which is of French-Malaysian origin (Furman, Lietz, \& Langer, 2006). A pantoum poem is a verse form consisting of 4 -line stanzas with a set pattern of repeated lines. Via the repeated lines of the pantoum poem we brought to the fore our experiences of professional development and the collaborative engagement. Furman et al. (2006) also noted that generating data through the arts stimulates an emotional response from the researcher and develops "personal understanding of the 'subject' of the data" (p. 25).

We also used the format of a tanka poem to capture our lived experiences, and what we would like to see happening with our integration into the institution and our professional development. The basic structure of a tanka poem is 5-7-5-7-7, indicating the number of syllables in each line (Furman et al., 2006). We followed this structure in the creation of our tanka poem, which enabled us to express our ideas and feelings collectively in just a few words. We elected to use a tanka poem because of its short construction, which allowed us to express our strong feelings and our authentic voice as ECAs (Furman, et al., 2006); it permitted an "effective way to express [those] inner feelings and thoughts" (Kanayama, 2003, p. 276). Also, the tanka has progressed in modern literature as a form of social engagement tool, which we utilised as we aimed to bring our plight as ECAs to the public platform (Breckenridge, 2016). This condensed poetic form captured our lived experiences and what we would like to see happen with our integration into the institution, as well with as our professional learning and development. We followed this structure in the creation of our tanka poem, using few words to enable us to express our feelings.

The sense-making process, which was our analysis process, took the form of discussions. After each creation, we engaged in a full plenary discussion of the meanings of each created artwork. As these meanings were made our "aim was to invite participants to further express and make meaning of their lived experiences as early-career academics as well as to reflect on the collective poetry-making process" (Pithouse-Morgan et al., 2016, p. 9). 


\section{Data Generation Process and Interpretation}

In generating data, we used the different art forms discussed above: collages, concept maps, and poems. Using the arts to generate data encouraged us to connect with each other and also stimulated a dialogue about our experiences as ECAs. As one of the ECAs reflected:

The process taught me how to work collectively towards a common goal. It also taught me a new and creative method of research, which is very practical and useful in our everyday lives. Finally, it taught me to appreciate the small things in life, which we often neglectoften a small artefact or piece of artwork/poetry can bring back interesting memories and cause you to be far more creative than you imagined. (Participant Alastair, 2014)

\section{Collages}

To create the collages within a 1-hour time frame, we sat in four groups consisting of four participants and collectively looked through magazines, newspaper articles, and catalogues for pictures and words as suggested by Khanare (2009). The intention of this exercise was to choose pictures or images that best captured our experiences and needs for our professional development. In the collages, we included pictures that stood out in one way or another, and that represented high and low points in our lives as ECAs within the university. We had to position ourselves, our encounters, and experiences in the collages. The self was important and central to our methodology (Samaras, 2011). Each chosen image told a story about our personal experiences and professional developmental needs, as well as the kinds of sustainable support we needed for our trajectory to becoming established academics. We also cut out words and sentences that added to what we aimed to articulate through our collages. As a group, we had to look at images gathered by each member of the group and collectively make choices based on which best spoke to what we wished to express about our experiences. We then collectively created the group collage as we negotiated and debated over construction of the collage:

When we created the collages, we had no boundaries as we approached the collages on equal footing. I believe the collage making process allowed us to reflect on what we required from our employer-a collegial and cordial working relationship-as we negotiated how the collages would eventually look. (Participant Lungile, 2014)

Four collages were produced within the negotiated process - an example is shown in Figure 1. 
Figure 1: Example of a Collage Constructed by ECAs

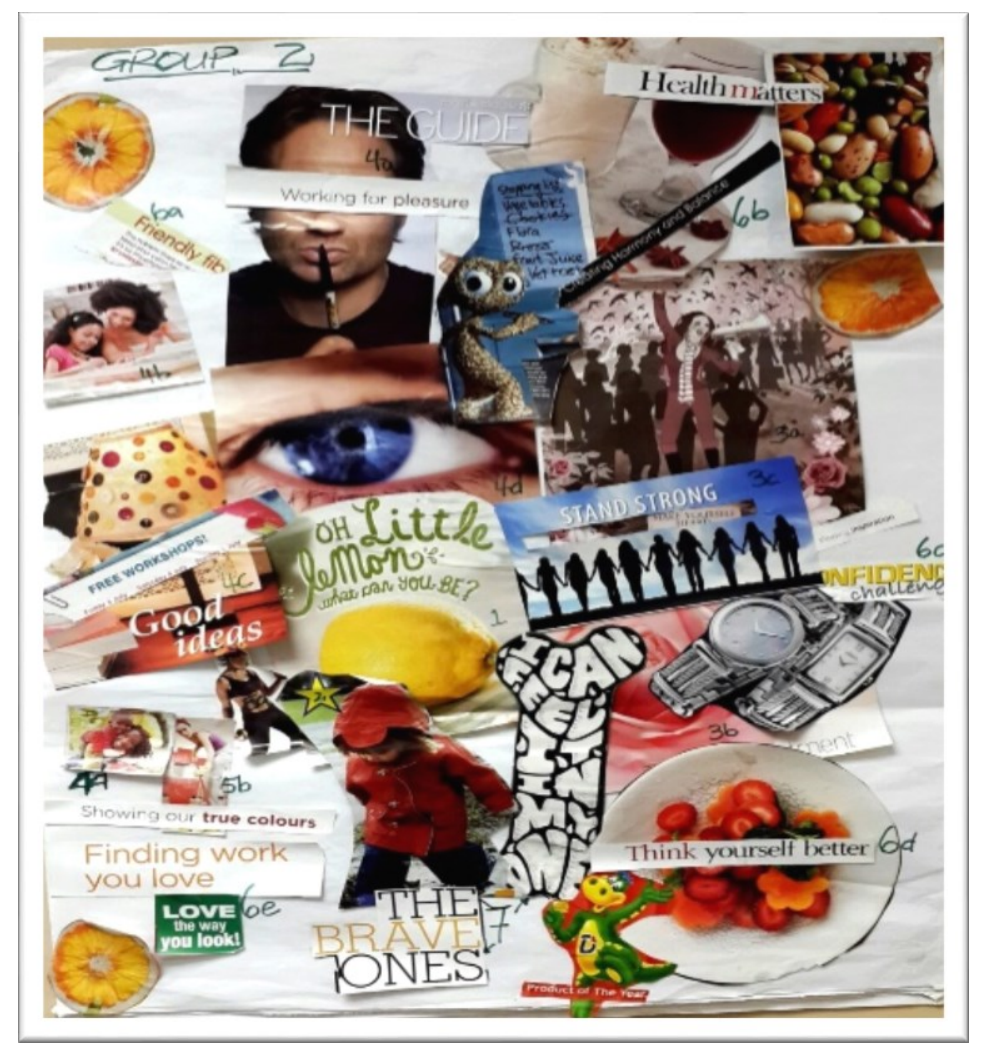

What emerged from our four collages spoke to our feelings and views of our standing within the institution. The collages also made visible what we regarded as imperative to our professional development. Drawing from our collage in Figure 1, the phrase "New kid on the block" signifies the common feeling we had as ECAs of being overwhelmed. We felt misplaced and not sure how to fit in. The feeling of inadequacy, anxiety, of being thrown in the deep end, was instigated by the fact that we were expected to teach, supervise postgraduate students, publish, and (for some ECAs) complete doctoral studies. The image of people holding hands with a caption, "Stand strong" in this collage, indicates what we viewed as the positive leap of the project towards effective development for us as ECAs. We identified that ECAs needed to work collaboratively and form supportive relationships amongst themselves, and partnerships with senior or experienced lecturers and professors.

We realised that we could not sustain our growth and development within the institution independently. Our collaborative venture would assist us to "Shape your life," as depicted in one of the collages created. This signified that as ECAs we also understood the significant role that we had to play as we took responsibility for our development and identified that we had the capacity to effect change. A sense of urgency was created amongst us as participants to actively participate in our own professional development.

\section{Concept maps}

After the creation of the collages the groups transcribed the meanings made from different collages into concept maps. The concept maps assisted in "compiling an inventory of denotations for the collage by listing the constituent elements systematically and cataloguing the literal meanings of the images and pictures posted on the collage" (van Schalkwyk, 2010, p. 683). The main images from the collages taken and numbered consecutively in the concept maps and sets of related concepts were grouped 
together. This allowed us to represent an understanding of relationships between important sets of concepts. For example, the collage in Figure 1-the picture of people holding hands-is captured by the transcription "Getting connected" (Number 2 of the concept map in Figure 2). This is grouped with related concepts such as team building, bringing together different ideas, and togetherness.

Figure 2: Concept Map Based on Collage Portrayed in Figure 1

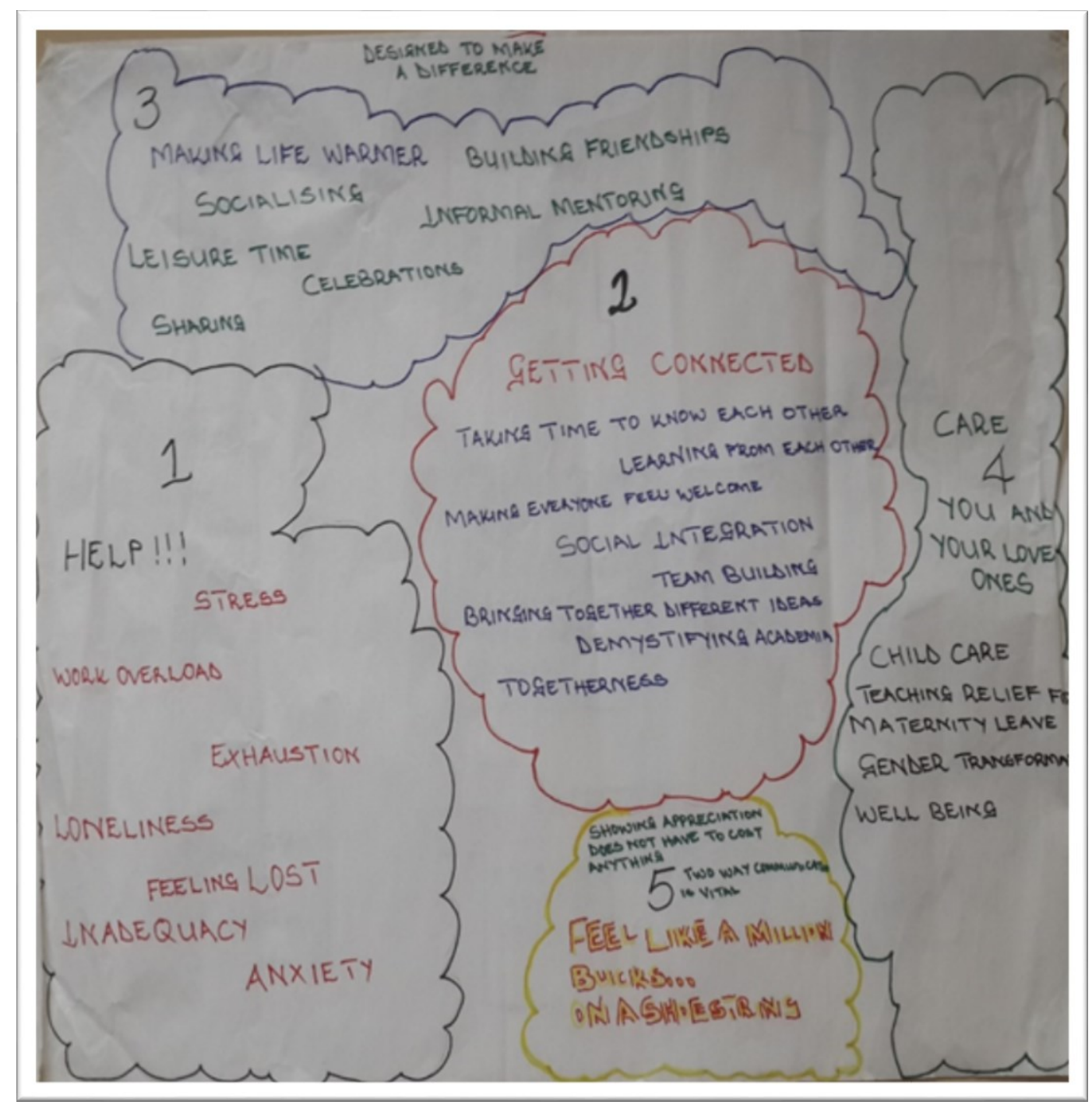

In our concept map in Figure 2, "making life warmer," "informal mentoring," and "sharing" depict how ECAs can be inducted in a nurturing environment so that the transition is positive and helpful. When we expressed making life warmer we meant making provisions such as mutual meeting spaces for ECAs and other academics so that they do not feel isolated and neglected. By informal mentoring, we expressed a need for an open door policy from our seasoned academics that would allow ECAs to approach them. While working with the seasoned academics there would be sharing of knowledge and skills to further develop the ECAs.

\section{Poems}

We then embarked on an artistic representation of our collective findings and our senior mentors introduced us to poems as an arts-based research medium (see Pithouse-Morgan et al., 2016). The 
artistic representation we felt was in keeping with our methodology and allowed us to present our work in an "evocative and trustworthy manner" (Furman et al., 2006, p. 26). We developed one pantoum poem from each concept map. We elected to create a pantoum poem because of its nature of repeated lines-because we wanted to create a lingering effect of the dilemma we found ourselves in as ECAs (Furman et al., 2006). An example of a pantoum poem is shown in Figure 3. This poem, which we titled "Designed to make a difference," successfully captured the plight of the ECAs in the project. To illustrate, Line 1 of Stanza 1 reads "Help!! Stress, work overload, feeling lost," and this line, repeated in Stanza 3, Line 4, evoked emotions felt by the ECAs. This line symbolises the emotions of feeling helpless, lost, unsupported, and overwhelmed by the amount of work expected of us as ECAs.

Figure 3: The Pantoum Poem, "Designed to Make a Difference"

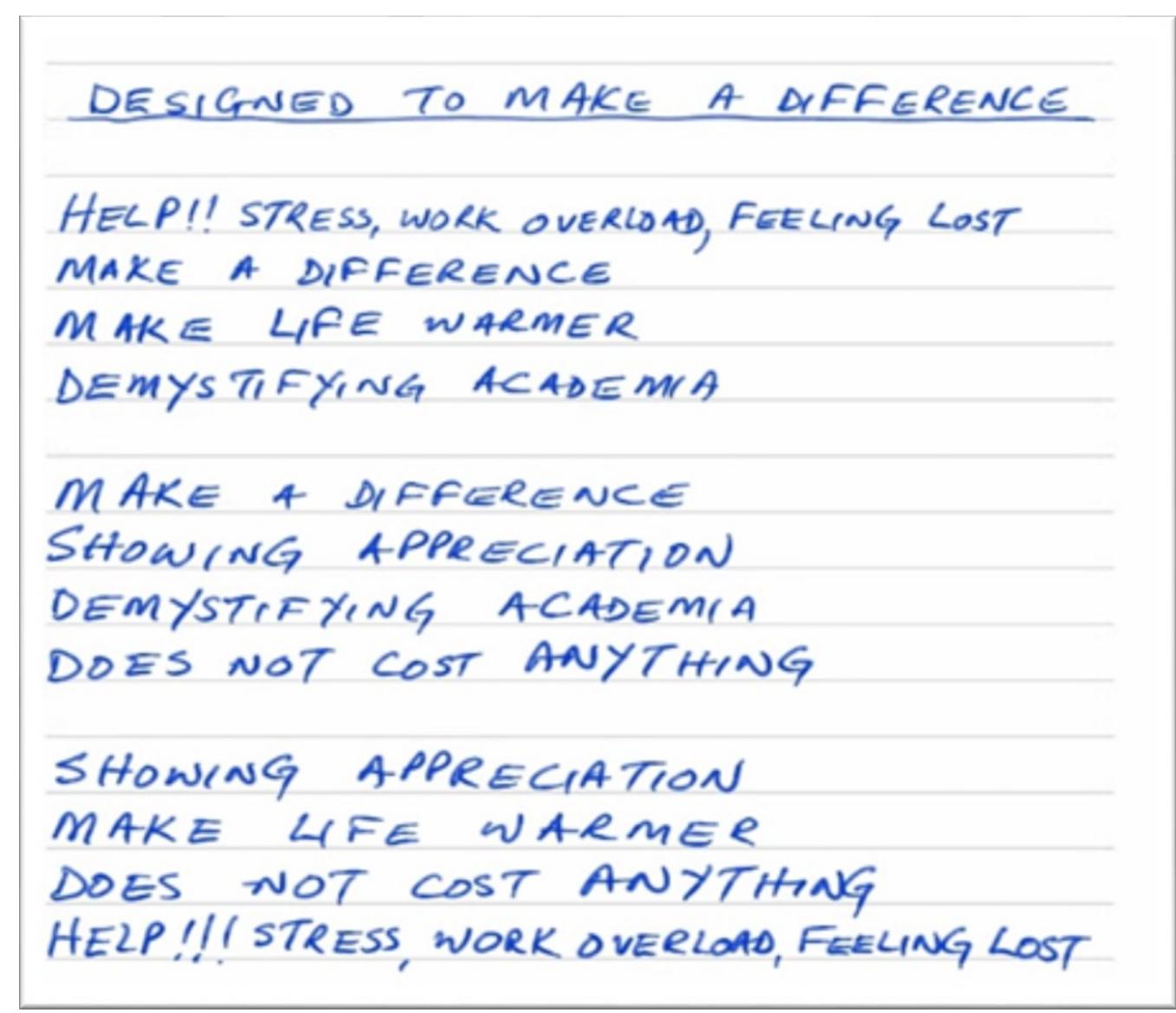

Next, all project participants worked together to develop the tanka poem shown in Figure 4 . In the second line of the tanka poem we expressed what we observed when we looked at professional development of ECAs within the university. The university in which we are all employed runs an induction programme comprising four modules for its entire academic staff, including newly appointed academics. However, through the tanka poem we expressed our view that although the programme met some of our needs, it did not address all of our needs. We felt that it seemed to focus on cognitive aspects and ignore the affective aspects of our work and lives as ECAs. In composing the tanka poem, we were also able to assert our view that the existing university policies do not address our needs. For example, we highlighted policies such as the "one size fits all" prescribed individual performance targets, especially in terms of research publications, as a source of continuing stress and contributing to a lack of collegiality among academics (Pithouse-Morgan et al., 2016). 
Figure 4: The Collective Construction of a Tanka Poem, "Issues of Concern"

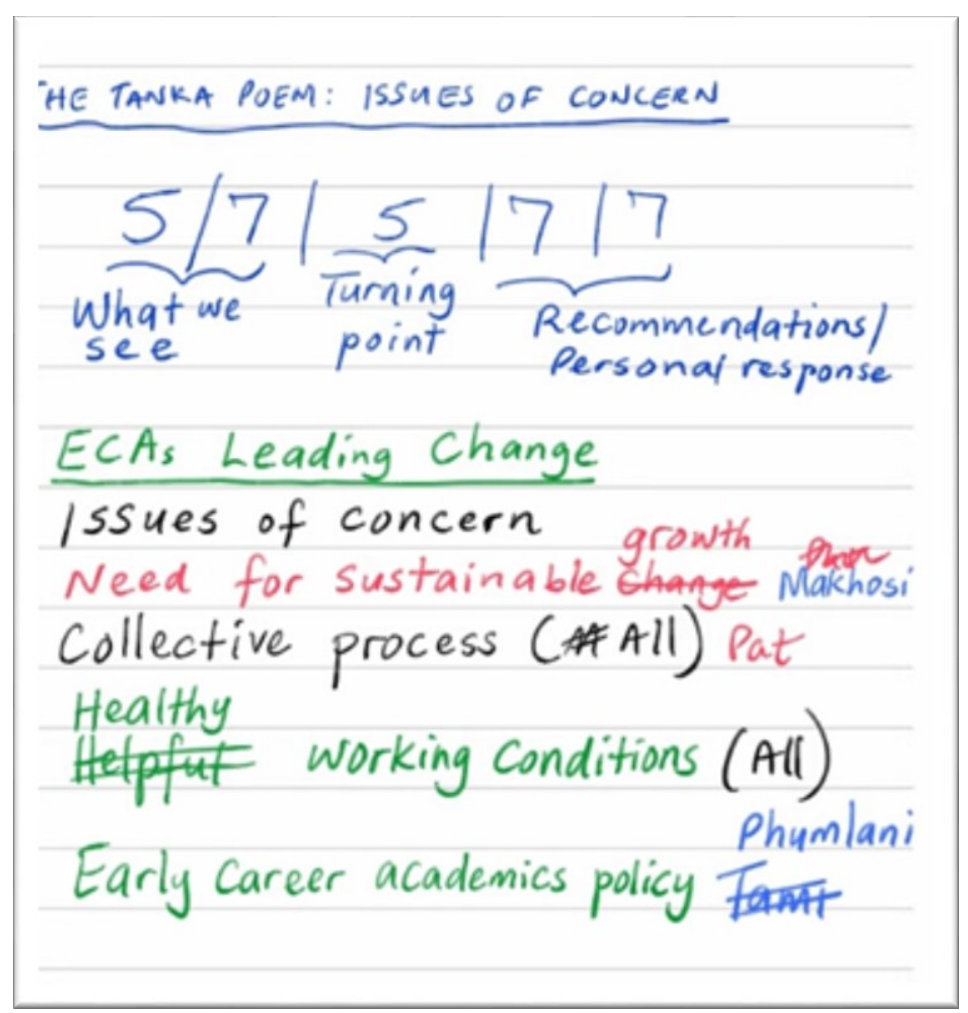

\section{ECAs' Collective Learning and Growth From the Arts-Based Self-Study Process}

As discussed, the various types of data provided different lenses through which to understand and express our feelings. As explained in the methodology section, we decided to use the tanka poem because of its short structure, which permitted us to express our strong feelings and our true voice as ECAs (Furman et al., 2006). Based on the tanka poem in Figure 4 above, the five overall themes that we identified were feeling overwhelmed, professional development, collaborative engagement, (un)healthy working conditions, and (lack of) policy for ECAs. These five themes are now further explored.

\section{Feeling overwhelmed}

This theme was strongly highlighted in the collages. Our general feeling was that, in the university, we were required to instantly start juggling teaching workloads, writing publications, research activities, acquiring funding for projects, and attaining doctoral degrees all at the same time (see PithouseMorgan et al., 2016). Such pressures placed us as early academics under strain and without any form of formal mentorship programme, which left us feeling lost and isolated (Price et al., 2015). There is a sense of vulnerability and uncertainty that ECAs encounter when joining academia as impending failure seems inevitable. Noted scholars such as Laudel and Gläser (2008, p. 388) asserted that ECAs "constitute the most vulnerable group in the system" and are therefore the first to suffer from the stress that has befallen this system. Furthermore, those scholars emphasised that the vulnerability that ECAs encounter stems from ECAs being uninformed about the structures and culture of academic institutions. 


\section{Professional development}

The NDP has made creation of the next generation of researchers a priority for South Africa. The professional development of those entering HEls as academics is therefore a necessity if this is to be realised.

Studies have shown that perhaps the most effective form of supporting ECAs' professional development and learning is mentoring, because it helps to reduce feeling of isolation and increase confidence and professional growth (Carey \& Weissman, 2010; Detsky \& Baerlocher, 2007), thus reducing the feeling of being overwhelmed. The poems and collages we constructed collectively depicted the shared feeling that outside of the project, we had not generally experienced mentoring that could lead to us being developed professionally. It is also crucial to note that the University of KwaZulu-Natal Transformation Charter (n.d.) states unequivocally that "mentorship and professional development programmes that develop staff to their full potential" (p. 2) will be devised. However, our experiences as ECAs point to the need for focused mentorship and professional development initiatives.

\section{Collaborative engagement}

This reflects what we thought could be the turning point. It conveys our view that we need to establish links with experienced lecturers and professors. Through our engagement, we realised that as ECAs we showed agency in that we saw ourselves as part of the solution towards our development. Through social constructivism as our theoretic frame, the collaboration between us and our mentors in the project demonstrated that learning by, and growth of, ECAs can only happen in a space where ECAs are actively involved in deliberations aimed at their development and professional support, and where seasoned academics provide continuous support through opening space for critical reflection by ECAs (see Powell \& Kalina, 2009). Again, in line with social constructivism, the process also allowed us the space for critical reflection, which facilitated our agency as ECAs as embedded in the collective artsbased methods that we used in this project (Taylor, 2014). This is also found in Samaras's (2011) argument that the collaborative arts-based self-study approach is interactive and aimed at improvement, and its outcomes demand immediate action.

\section{Healthy working conditions}

Establishing healthy working conditions is critical in successfully integrating ECAs into the higher education environment. We identified four trends in this regard, namely, a collegial, invitational, appreciative work climate; the cultivation of good ideas, care, love, and hope; for the "tools of the trade" and guidance to be readily available; and finally, for the creation of a nurturing space to think and to voice. We felt that incorporating these trends within higher education institutions would significantly benefit ECAs and provide a sound working environment for the next generation of academics. Considering the work climate, the benefits of a positive working environment and its impact on organisational performance, employee satisfaction, and employee effectiveness are well documented in the literature and span studies from 1985 by Schneider and Bowen to more recent studies by Kozlowski and llgen (2006). Regarding the second trend of good ideas, care, love, and hope, George (1990) found that the overall feelings within an organisation affect how individuals feel about that organisation. Specifically, positive emotions can reduce absenteeism, intention to quit, and conflict while increasing cooperation and job performance (Barsade, 2002; George \& Brief, 1992; Jinnett \& Alexander, 1999). Tools of the trade refer to both the practical know-how as well as other basic resources for research projects. In addition to mentorship and other forms of guidance, Bazeley et al. (1996) noted the importance of making available resources such as start-up funding so that research work can actually proceed. Finally, the fourth trend of a nurturing space to think and to voice relates strongly to the previous three points and is the outcome of a collegial work climate and an institution where care, love, and hope prevail. Given our feelings of being overwhelmed, it is important 
that ECAs are provided with time and space in order to develop themselves as academics (Bazeley et al., 1996).

\section{Policy for ECAs}

Portrayed in the tanka poem, the need for a policy that will consider ECAs in a holistic way is emphasised. From our voices as ECAs, it is clear that unhealthy conditions emanated from the pressure imposed on ECAs to publish and supervise postgraduate students without proper guidance and mentoring. For some ECAs, further pressure was imposed by the number of students they are teaching in their undergraduate lecture rooms. The search for solutions made us realise the need for an earlycareer policy, which we think will allow the university to have a focused initiative aimed at creating a conducive space for ECAs' learning and growth.

The ECAs policy would aim at a holistic approach and take into consideration that ECAs should be treated "unlike." Unlike treatment, to us, meant that the university required specific policies that speak to issues of ECAs separate from the general policies governing academics. The policies should be grounded on how ECAs will be supported in the form of mentoring and fair and manageable workloads, thus ensuring that they are able to cope with their work demands. Our reflections indicated that when it comes to workload and performance management, the university does not consider that there are ECAs and experienced academics and these groups cannot be treated alike.

Another element of policy we thought was important was to look at what will be the benefits of those involved in developing ECAs. Currently, we realised that those who are committed in mentoring and supporting ECAs do it out of their own interest, and their work is hardly acknowledged and rewarded by the institution. Based on the value of mentoring (Debowski, 2012), we believe that mentoring of ECAs by experienced academics is important (Hemmings \& Hill, 2009). Hence the need for an earlycareer academics policy, which we thought would allow the university to have a focused initiative aimed at creating a conducive space for ECAs' learning and growth.

\section{Going Public and Moving Forward}

In order to stimulate change beyond ourselves, and make the ECA experience more conducive in addressing the needs of the South Africa higher education sector, we as ECAs concluded that our lived experiences and encounters needed to be visible. As such, we needed to go public and engage with both the university population and the higher education sector as a whole. To this end, we first held a university seminar to engage with the university population. This was later followed by a conference presentation, which was attended by various stakeholders in the higher education sector.

\section{The university seminar}

Our first step in going public was to hold a seminar to which relevant university management and stakeholders were invited. In this seminar, we raised some issues such as an unhealthy working environment, the need for mentoring, the dearth of resources, and the need for an ECA policy because we felt the current policies do not accommodate the needs of ECAs. We concluded that it is a necessity that ECAs should not be treated like the senior academic staff in their early years of employment. While we argued that there is a need for collaboration and teamwork amongst the ECAs themselves, we also pointed out that senior staff should take part in this collaboration to engender success, as opposed to a sink-or-swim approach adopted by some senior academics (Pithouse-Morgan et al., 2016).

Responding to our seminar presentation, senior scholars present raised a number of questions, which included the following: "Have you identified role models, not just within your school or discipline but 
across the university staff?" Moreover, "Do you have a voice and platform to raise all these issues such that the school or college management will hear you and make a difference?" We responded to these questions by clarifying that as ECAs, through our individual efforts, we have attempted to make connections with senior staff, and that many of us have met with dismissive responses. As one of the ECAs shared in the seminar: "Upon my arrival in the institution, it felt as if someone threw a bucket full of ice water. Academics responding with stony looks which spoke volumes." However, there were also some positive stories that we shared. For example, one ECA said: "In my discipline, senior colleagues provided a working environment which was conducive for learning and growth." The ECA indicated that "through 'corridor dialogues' colleagues guided me such that I was able to learn the tools for trade in academia." However, we still maintained that, possibly because of lack of recognition of their informal mentoring of new staff, many senior academics did not appear keen to assist us.

A concern raised by senior academics was that professional and academic growth is not only an outside-in process. We acknowledged this concern and further clarified that in our project we also came to the conclusion that although it is imperative for the institution to provide an effective outsidein process of development, through the project ECAs also learned to be active role players in their own agency-collectively and individually.

Furthermore, the reaction of some senior scholars was that ECAs should be cautious of perpetuating a "victim syndrome." They maintained that ECAs should not undermine themselves and their capacity for systemic change, arguing that ECAs need to be innovative in solving their own problems. We responded that we do have a voice, but often lack the space to voice our experiences and views.

\section{The conference presentation.}

Following the seminar presentation, we presented our study on a more general platform in order to engage with the South African higher education sector as a whole. Specifically, we presented at a university teaching and learning conference with the main theme of Re-imagining higher education policy implementation: Can policy learn from practice? Through our conference presentation, we explored how responsive and innovative pedagogies in academic staff development could help to reimagine higher education policy and practice. The intention was to demonstrate how policy can learn from collective arts-based practices that could allow ECAs to spearhead their own personal and professional development.

Participating in the conference was a significant highlight of the project. Feedback from the audience ranged from questions about our arts-based methods, to those about lessons from our practical experiences. There was consensus that arts-based research methods have a place in contemporary research spaces and as a teaching and learning strategy in our lecture rooms. We agreed that artsbased methods can enable us to inject creativity into our knowledge production as well as our teaching and our professional learning and development.

\section{Conclusion}

Through the arts-based collective self-study research project, we as ECAs demonstrated that there is a need for institutions to explore more innovative ways of developing ECAs. The arts-based methods used in this study promoted effective collaborative means to explore issues of concerns for ECAs. This was made imperative by the need to meet the DHET need to respond to the National Development Plan of creating the next generation of researchers, and also to meet the demanding task of ECAs' growth and advancement into industrious researchers (Balfour \& Lenta, 2009). They address what had been expressed in this work by ECAs as we shared our personal experiences and challenges, showing how we felt overwhelmed when entering $\mathrm{HEl}$-trying to balance research, teaching, and other 
demands of academic life. In addressing these issues a social constructivist approach was used, as we collectively became self-motivated professionals seeking solutions to our plight as ECAs.

The arts-based methods also assisted us to identify a strong need for collaborative engagement between ECAs and experienced academics. We took a leading role in our professional learning and development, which also helped us realise that there are senior academics who are willing to offer mentorship to us. Moving forward, there is a need to form coordinated university communities of practice to facilitate the engagement, learning, development, and promotion of ECAs (Cox, 2013; Remmik et al., 2011). Networking will bring with it the added advantages of confidence building and a sense of belonging to the institution.

To address the challenge of the lack of literature that addresses the development and nurturing of ECAs, we were able to demonstrate what could be achieved by exploring inventive methods such as the collective arts-based self-study. It allowed for our personal engagement as we formed part of the research process through sharing our stories to look for solutions rather than having solutions imposed on us.

We view this process as the foundation for influencing the future development of ECAs. We identified the need to expand on this project and explore collaboration across all South African institutions, using arts-based methods, as ECAs bring their own unique stories of experience. This prompts a further exploration of incorporating narrative enquiry to make sense of the stories of becoming and being academics within a transforming university landscape (Pithouse-Morgan et al., 2016), allowing the voices of the ECAs - through their stories - to be part of the solution finding space, as the development of early-career academics is prioritised by all institutions.

\section{Acknowledgements}

We gratefully acknowledge the other project participants who did not contribute in the writing of this paper but contributed to generation of the data produced in the project.

We gratefully acknowledge funding from the UKZN Teaching \& Learning Office (UTLO) Institutional Research Grant for the project: New Scholarship in Teaching and Learning in Higher Education.

\section{References}

Balfour, R., \& Lenta, M. (2009). Research capacity development: A case study at the University of KwaZulu-Natal, 2003-2007. South African Journal of Higher Education, 23(1), 8-20.

Barsade, S. G. (2002). The ripple effect: Emotional contagion and its influence on group behavior. Administrative Science Quarterly, 47, 644-675.

Bazeley, P., Kemp, L., Stevens, K., Asmar, C., Grbich, C., Marsh, H., \& Bhathal, R. (1996). Waiting in the wings: A study of early career academic researchers in Australia. Canberra, Australia: Australian Government. Retrieved from http://www.researchsupport.com.au/waiting in the wings.pdf

Bodner, G., Klobuchar, M., \& Geelan, D. (2001). The many forms of constructivism. Journal of Chemical Education, (8), 1134.

Breckenridge, J. P. (2016). The reflexive role of tanka poetry in domestic abuse research. Journal of Research in Nursing, 1-14. Retrieved from http://jrn.sagepub.com/content/early/2016/05/27/1744987116649635.full.pdf+html 
Butler-Kisber, L., \& Poldma, T. (2010). The power of visual approaches in qualitative inquiry: The use of collage making and concept mapping in experiential research. Journal of Research Practice, 6(2), Article M18.

Carey, E. C., \& Weissman, D. E. (2010). Understanding and finding mentorship: A review for junior faculty. Journal of Palliative Medicine, 13(11), 1371-1379.

Cox, M. D. (2013). The impact of communities of practice in support of early-career academics. International Journal for Academic Development, 18(1), 18-30. http://dx.doi: 10.1080/1360144X.2011.599600

Daley, B. J. (2004). Using concept maps in qualitative research. Concept Maps: Theory, Methodology, Technology, Proceedings of the First International Conference on Concept Mapping, Pamplona, Spain. Retrieved from http://cmc.ihmc.us/papers/cmc2004-060.pdf

Debowski, S. (2012). The new academic: A strategic handbook. Buckingham, UK: Open University Press.

Department of Higher Education and Training. (2013). White paper for post-school education and training: Building an expanded, effective and integrated post-school system. Retrieved from http://www.justice.gov.za/commissions/FeesHET/docs/2013-WhitePaper-Post-

SchoolEducationAndTraining.pdf

Department of Higher Education and Training. (2015). Strategic plan 2015/16-2019/20. Retrieved from http://www.dhet.gov.za/Strategic\%20Plans/Strategic\%20Plans/Department\%20of\%20Higher\%20 Education\%20and\%20Training\%20Strategic\%20Plan\%202015-16\%20-\%202019-20.pdf

Detsky, A. S., \& Baerlocher, M. O. (2007). Academic mentoring-How to give it and how to get it. Journal of the American Medical Association, 297(19), 2134-2136.

Furman, R., Lietz, C., \& Langer, C. (2006). The research poem in international social work: Innovations in qualitative methodology. International Journal of Qualitative Methods, 5(3), 24-34.

Geber, H. (2009). Research success and structured support: Developing career academics in higher education. South African Journal of Higher Education, 23(4), 674-689.

Geber, H., \& Nyanjom, J. (2009). Mentor development in higher education in Botswana: How important is reflective practice? South African Journal of Higher Education, 23(5), 894-911.

George, J. M. (1990). Personality, affect, and behavior in groups. Journal of Applied Psychology, 76, 299-307.

George, J. M., \& Brief, A. P. (1992). Feeling good-doing good: A conceptual analysis of the mood at work-organizational spontaneity. Psychological Bulletin, 112(2), 310-329.

Harrison, L., Pithouse-Morgan, K., Conolly, J., \& Meyiwa, T. (2012). Learning from the first year of the Transformative Education/al Studies (TES) project. Alternation, 19(2), 12-37.

Hemmings, B. (2012). Sources of research confidence for early career academics: A qualitative study. Higher Education Research and Development, 31(2), 171-184.

Hemmings, B., \& Hill, D. (2009). The development of lecturer research expertise: Towards a unifying model. Issues in Educational Research, 19(1), 14-24.

Hemmings, B., \& Kay, R. (2010). Research self-efficacy, publication output, and early career development, International Journal of Educational Management, 24(7), 562-574.

Hopwood, N., \& Stocks, C. (2009). Development for early career academics: Encouraging signs, but are we talking past each other? International Journal for Academic Development, 14(3), 169-171.

Hord, S. (2009). Professional learning communities: Educators work together towards a shared purpose for improved student learning. National Staff Development Council, 30(1), 40-43. 
Jinnett, K., \& Alexander, J. A. (1999). The influence of organizational context on quitting intention: An examination of treatment staff in long-term mental health care settings. Research on Aging, 21(2), 176-205.

Kanayama, T. (2003). Ethnographic research on the experience of Japanese elderly people online. New Media \& Society, 5(2), 267-288.

Khanare, F. (2009). "We are not alone": Taking an asset-based approach in responding to the needs of orphaned and vulnerable children. In C. Mitchell \& K. Pithouse (Eds.), Teaching and HIV \& AIDS (pp. 90-104). Johannesburg, South Africa: MacMillan.

Kilic, M., \& Cakmak, M. (2013). Concept maps as a tool for meaningful learning. International Journal of New Trends in Education and their Implications, 4(4), 152-164.

Kozlowski, S. W. J., \& Ilgen, D. R. (2006). Enhancing the effectiveness of work groups and teams. Psychological Science in the Public Interest, 7(3), 77-124.

Laudel, G., \& Gläser, J. (2008). From apprentice to colleague: The metamorphosis of early career researchers. Higher Education, 55(3), 387-406.

Mannay, D. (2010). Making the familiar strange: Can visual research methods render the familiar setting more perceptible? Qualitative Research, 10(1), 91-111.

National Planning Commission. (2013). National Development Plan 2030: Our future-make it work. Pretoria, South Africa: Presidency.

Novak, J. D., \& Cañas, A. J. (2008). The theory underlying concept maps and how to construct and use them (Technical Report IHMC CmapTools 2006-01 Rev 01-2008). Retrieved from http://cmap.ihmc.us/docs/theory-of-concept-maps

Philpott, J., \& Batty, H. (2009). Learning best together: Social constructivism and global partnerships in medical education. Medical Education, 43, 923-925.

Pithouse-Morgan, K., Naicker, I., Pillay, D., Masinga, L., \& Hlao, T. (2016). "Sink or swim?": Learning from stories of becoming academics within a transforming university terrain. South African Journal of Higher Education, 30(1), 1-20.

Polly, D. (2011). Teachers' learning while constructing technology-based instructional resources. Journal of Education Technology, 42(6), 950-961.

Powell, K., \& Kalina, C. (2009). Cognitive and social construction: Developing tools for an effective classroom. Education, 1, 241-250.

Price, E., Coffey, B., \& Nethery, A. (2015). An early career academic network: What worked and what didn't. Journal of Further and Higher Education, 39(5), 680-698.

Prosser, J., \& Loxley, A. (2008). Introducing visual methods. Retrieved from National Centre for Research Methods website: http://eprints.ncrm.ac.uk/420/1/MethodsReviewPaperNCRM010.pdf

Raht, D., Smith, J., \& MacEntee, K. (2009). Engaging youth in addressing HIV \& AIDS: Creative and participatory methods in the classroom. In C. Mitchell \& K. Pithouse (Eds.), Teaching and HIV \& AIDS (pp. 219-236). Johannesburg, South Africa: MacMillan.

Remmik, M., Karm, M., Haamer, A., \& Lepp, L. (2011). Early-career academics' learning in academic communities. International Journal for Academic Development, 16(3), 187-199. http://dx.doi:10.1080/1360144X.2011.596702

Richardson, L., \& St Pierre, E. A. (2005). Writing: A method of inquiry. In N. K. Denzin, \& Y. S. Lincoln, (Eds.), The Sage handbook of qualitative research (3rd ed., pp. 959-978). Thousand Oaks, USA: SAGE. 
Richardson, V. (1997). Constructivist teacher education: Building a world of new understandings. London, UK: Routledge Falmer.

Samaras, A. P. (2011). Self-study teacher research: Improving your practice through collaborative inquiry. Thousand Oaks, USA: SAGE.

Schneider, B., \& Bowen, D. E. (1985). Employee and customer perceptions of service in banks: Replication and extension. Journal of Applied Psychology, 70(3), 423-433.

Taylor, P. C. (2014). Constructivism. In R. Gunstone (Ed.), Encyclopedia of science education. Dordrecht, Netherlands: Springer. doi 10.10071978-94-007-6165-0-102-2

Thomas, K., McNaught, C., Wong, K., \& Li, Y. (2011). Early career academics' perceptions of teaching and learning in Hong Kong: Implications for professional development. International Journal for Academic Development, 16(3), 257-268.

Threadgold, T. (2003). Cultural studies, critical theory and critical discourse analysis: Histories, remembering and futures. Linguistik Online, 14(2). Retrieved from http://www.linguistikonline.de/14 03/threadgold.html

University of KwaZulu-Natal. (n.d.). The UKZN transformation charter. Retrieved from http://www.ukzn.ac.za/docs/general-docs/the-ukzn-transformation-charter.pdf?sfvrsn=0

Van Schalkwyk, G. J. (2010). Collage life story elicitation technique: A representational technique for scaffolding autobiographical memories. The Qualitative Report, 15(3), 675-695.

Warhurst, R. (2008). "Cigars on the flight-deck": New lecturers' participatory learning within workplace communities of practice. Studies in Higher Education, 33(4), 453-467.

Weber, S. (2014). Arts-based self-study: Documenting the ripple effect. Perspectives in Education, $32(2), 8-20$.

Williams, C. G. (1998). Using concept maps to assess conceptual knowledge of function. Journal for Research in Mathematics Education, 29(4), 414-421. 